Article

\title{
Creating World-Class Gathering Places for People and Wildlife along the Detroit Riverfront, Michigan, USA
}

\section{John H. Hartig ${ }^{1, *}$ and Mark C. Wallace ${ }^{2}$}

1 Detroit River International Wildlife Refuge, U.S. Fish and Wildlife Service, 9311 Groh Road, Grosse Ile, MI 48138, USA

2 Detroit Riverfront Conservancy, 600 Renaissance Center, Suite 1720, Detroit, MI 48243-1802, USA; E-Mail: mark.wallace@detroitriverfront.org

* Author to whom correspondence should be addressed; E-Mail: johnhartig1@gmail.com; Tel.: +1-734-692-7608; Fax: +1-734-692-7603.

Academic Editor: Vincenzo Torretta

Received: 8 September 2015 / Accepted: 4 November 2015 / Published: 13 November 2015

\begin{abstract}
Metropolitan Detroit, Michigan, USA is the automobile capital of the world, part of the industrial heartland and Rust Belt, and a major urban area. For over two centuries, the Detroit River was perceived as a working river that supported commerce and industry. Like many other large North American cities, the Motor City made the Detroit River its back door, with businesses facing inland and away from the river. Compounding the problem, Detroit became indifferent to the water pollution that was perceived as a necessary by-product of industrial progress. By the 1960s, the Detroit River was one of the most polluted rivers in North America. Today, the cleanup and recovery of the Detroit River represent one of the most remarkable ecological recovery stories in North America with the return of bald eagles, peregrine falcons, osprey, lake sturgeon, lake whitefish, mayflies, and more. Out of this recovery has come two transformational projects - the Detroit River International Wildlife Refuge and the Detroit RiverWalk - that are helping change the perception of the region from that of a Rust Belt city to one of a leader of urban sustainability that reconnects people to nature, improves quality of life, promotes sustainable redevelopment, and enhances community pride. Key lessons learned include: recruit a well-respected champion; ensure broad support from key stakeholder groups; establish core delivery team, focused on outcomes; build trust; adopt a strategic approach to community engagement, creating a connected community; evoke a sense of place; and measure and celebrate successes to sustain momentum.
\end{abstract}


Keywords: Detroit; industrial heartland; waterfront redevelopment; place-making; community engagement; sustainability

\section{Introduction}

The traditional use of most North American urban waterfronts has been shipping, manufacturing, and associated land-based transportation and storage facilities [1]. These waterfronts served these functions very well. Indeed, these working waterfronts were the sites where the Industrial Revolution was manifest and where the wealth of cities and the nations was made [2].

Then after World War II, a decline of many working, industrial waterfronts began as a result of a number of factors, including:

- a switch from bulk cargo shipping to containerization that created efficiencies and reduced transportation costs;

- more efficient intermodal transportation that contributed to relocating many manufacturing operations away from waterfronts;

- economic recessions;

- transportation policies that built highway systems that encouraged outward migration and urban sprawl;

- changes in industrial technology and international competitiveness;

- the shift of many local economies from one dominated by manufacturing to one dominated by the service industry (i.e., post-industrial); and

- other socio-economic factors [3-5].

This decline of working, industrial waterfronts created much underutilized and vacant waterfront land that was often an eyesore to the community. These underutilized and vacant waterfront lands increasingly became separated from the physical, social, and economic activity of the rest of the city [2].

Then in the late-1970s a number of factors came together in the United States to spur urban waterfront revitalization, including the 1972 U.S. Clean Water Act that catalyzed the cleanup of waterways, an energy crisis in the early-1970s that resulted in gasoline shortages, tax incentives that encouraged creative reuse of older buildings, and increased demand for public access to waterfronts for recreational use [1]. Such post-industrial waterfront redevelopment is now common throughout many North American cities like Boston, Baltimore, Toronto, Seattle, Vancouver, San Francisco, and many more, and is becoming more common on other continents [6-8]. In most cases, post-industrial waterfronts are being transformed into more publicly-accessible waterfronts that support recreational activities, entertainment, leisure areas, mixed-use office and residential development, and associated retail services. Indeed, such post-industrial waterfront redevelopment has both well-known benefits, like creation of green spaces and jobs, reduction of urban sprawl, and enhancement of recreation and connectivity, and has well-known barriers, including potential for biological, physical, and chemical impacts, uncertainty about liability and cleanup costs, high redevelopment costs, and challenges of securing financial support [9]. 
Internationally, metropolitan Detroit, Michigan, USA is probably best known as the automobile capital of the United States, the home of Motown Music, and a quintessential Rust Belt city characterized by over a $60 \%$ decline in population, economic decline, and urban decay. However, Detroit has a rich history that can be described as evolving through a number of paradigm shifts where Detroit impacted the nation and world, including responding to the most recent sustainability paradigm shift by creating unique gathering places for people and wildlife along the Detroit riverfront to help achieve more balanced and continuous environmental, social, and economic progress toward the goal of sustainable development. Much like the effort to recreate front porches on houses in U.S. cities to encourage a sense of community and foster sustainable development [10], creation of publicly-accessible waterfronts in urban areas with riparian habitat and other ecological features can help recreate gathering places for both wildlife and people with many social, economic and environmental benefits.

The purpose of this manuscript is to explore metropolitan Detroit as a case study of sustainable waterfront redevelopment by:

- reviewing how Detroit has responded to major paradigm shifts, including the current challenge of sustainability;

- reviewing and evaluating two case studies of how metropolitan Detroit is today creating gathering places for people and wildlife along the Detroit riverfront to foster sustainable redevelopment and reap its many social, economic, and environmental benefits;

- sharing selected examples of recent efforts being taken to link Detroit with metropolitan communities to overcome historical division and foster a more sustainable future on a regional scale; and

- documenting lessons learned in the spirit of cooperative learning for sustainable development.

It might seem incongruous that Detroit is pursuing a waterfront "sense of place" in this industrial heartland of North America that is facing considerable economic, social, and environmental challenges. But that is precisely what it is being done along the shores of the Detroit River through the efforts of the Detroit River International Wildlife Refuge (DRIWR), the Detroit Riverfront Conservancy, and their many partners. Such efforts are critically important if we want to inspire the next generation of sustainability entrepreneurs and conservationists in urban areas because that is where most people on our planet now live.

\section{Brief History of Waterfront Development along the Detroit River}

Native Americans lived along the Detroit River in the region that is now Detroit for thousands of years, attracted by water transportation advantages and exceptional natural resources. The first European settlement was established in Detroit in 1701, three quarters of a century before the founding of the United States. Since its establishment, Detroit has experienced much change that can be described as responding to paradigm shifts. Thomas Kuhn described and popularized this concept of a significant change in thinking that results in a completely changed view or outlook and called them "paradigm shifts" [11]. Kuhn argued that scientific advancement is not evolutionary, but rather is a "series of peaceful interludes punctuated by intellectually violent revolutions", and in those revolutions "one 
conceptual world view is replaced by another" [11]. It is a revolution, a transformation, or even a metamorphosis. They do not just happen, but are driven by agents of change.

For example, the invention of the printing press by Johann Gutenberg in the 1440s brought about a paradigm shift that allowed books to be readily available to all people. Similarly, personal computers and the internet in recent years have brought about a paradigm shift in both personal and business environments.

Native Americans were the earliest inhabitants to live along the $51.5 \mathrm{~km}$ Detroit River (that links the upper Great Lakes with the lower Great Lakes) and in its watershed, attracted by the plethora of freshwater and exceptional fish, wildlife, and plant resources associated with them [12]. For thousands of years they lived in relative harmony with their environment. Since then, metropolitan Detroit has gone through a number of paradigm shifts. Change is always difficult, however, metropolitan Detroit has a long history of adapting well to paradigm shifts and meeting the needs of the nation and indeed the world. Presented in Table 1 is a summary of the major paradigm shifts that have affected metropolitan Detroit and how it has responded. Indeed, it can be argued that Detroit has historically demonstrated ingenuity, creativity, and technological excellence in meeting the needs of the region, nation, and world.

Table 1. Paradigm shifts affecting metropolitan Detroit and how it has responded.

\begin{tabular}{|c|c|}
\hline Paradigm Shift & Description \\
\hline $\begin{array}{l}\text { Fur Trade Era } \\
(1600 s-1700 s) \text { [13] }\end{array}$ & $\begin{array}{l}\text { - Detroit was literally created in response to European demand for hats made from beaver pelts } \\
\text { - The outpost at Detroit became a strategic move in protecting French trapping interests and it } \\
\text { went on to become a leading processer and exporter of furs during the Fur Trade Era } \\
\text { - Europeans exported 50,000 skins annually until, by } 1800 \text {, beaver were near extinction }\end{array}$ \\
\hline $\begin{array}{l}\text { Ship Building } \\
\text { (late-1700s-mid-1900s) } \\
{[14]}\end{array}$ & $\begin{array}{l}\text { - Detroit became a major center of trade and commerce, and an embarkation point for the lands } \\
\text { farther west } \\
\text { - To meet the pressing demand for transportation of passengers and freight, Detroit became } \\
\text { one of the greatest ship building ports in the U.S. (hundreds of ships were built along the } \\
\text { waterfront; during the } 1890 \mathrm{~s} \text {, more ships were built along the Detroit River than any other } \\
\text { city in America); shipbuilding provided jobs and supported families locally, but it also } \\
\text { impacted the nation and world through billions of dollars of commerce and trade } \\
\text { - From } 1801 \text { to } 1960 \text { at least } 655 \text { ships were built at yards and locations from the lower Rouge } \\
\text { - River to the mouth of the Detroit River } \\
\text { - In } 1819 \text { the Detroit River was declared a public highway by Act of Congress } \\
\text { During the } 1890 \mathrm{~s} \text {, more passenger trade went out of Detroit than anywhere in the world }\end{array}$ \\
\hline $\begin{array}{l}\text { Automobile } \\
\text { Manufacturing [15] }\end{array}$ & $\begin{array}{l}\text { - Metropolitan Detroit's expertise in building steam engines for ships and practical experience } \\
\text { in manufacturing coaches and carriages positioned it well for addressing the automotive } \\
\text { paradigm shift } \\
\text { - Detroit's first car company started in } 1899 \\
\text { - Henry Ford created more efficient manufacturing systems, including assembly lines } \\
\text { - By } 1913 \text { the industry grew to the point where there were } 43 \text { different automobile companies } \\
\text { operating in the Detroit metropolitan area } \\
\text { - By } 1919,45 \% \text { of Detroit's } 308,520 \text { industrial employees were employed in the automobile } \\
\text { industry and Detroit had become the Motor City and one of the largest industrial } \\
\text { manufacturing centers in the world }\end{array}$ \\
\hline
\end{tabular}


Table 1. Cont.

\begin{tabular}{|c|c|}
\hline Paradigm Shift & Description \\
\hline & $\begin{array}{l}\text { - Following the Japanese attack on Pearl Harbor in 1941, the U.S. plunged into World War II } \\
\text { - U.S. President Roosevelt recognized the need to help supply Europe with the implements of } \\
\text { war and called for the U.S. to become the great "Arsenal of Democracy" } \\
\text { - Detroit responded by redeploying its vast industrial capacity to play a critical role in the } \\
\text { ultimate Allied victory in } 1945 \\
\text { - In } 1942 \text {, all automobile assembly lines in metropolitan Detroit ceased production of civilian } \\
\text { - } \text { - In total, metropolitan Detroit companies received contracts worth about } \$ 14 \text { billion or } 10 \% \\
\text { - } \text { of all U.S. military output in } 1943 \\
\text { - Dy } 1944 \text { metropolitan Detroit was the leading supplier of military goods in the U.S. } \\
\text { employed approximately } 610,000 \text { people in military production }\end{array}$ \\
\hline Sustainability [15] & $\begin{array}{l}\text { - Since the } 1950 \text { s, Detroit has experienced over a } 60 \% \text { decrease in population (1950 } \\
\text { population: nearly } 1.9 \text { million; } 2014 \text { population: } 713,777 \text { ), a considerable decline in industry, } \\
\text { rising unemployment, increased cost of living, decreased access to city services, and } \\
\text { increased crime } \\
\text { - From the } 1960 \text { s through the early-1980s most environmental issues were characterized by } \\
\text { adversarial relationships that polarized environment and development; much of the argument } \\
\text { centered on either protecting the environment or furthering development } \\
\text { - The concept of sustainable development brought the free enterprise system together with the } \\
\text { environmental movement to see that a healthy economy and a healthy community require a } \\
\text { healthy environment } \\
\text { - Sustainable development was popularized and endorsed by business and legitimized through } \\
\text { the work of World Commission on Environment and Development and its book titled Our } \\
\text { Common Future [16] } \\
\text { In } 1999 \text {, Detroit hosted the National Town Hall Meeting for the President's Council on } \\
\text { Sustainable Development at its Cobo Convention Center, attracting over } 3,000 \text { people } \\
\text { - Metropolitan Detroit businesses became early leaders of sustainability, recognizing that to } \\
\text { ensure long-term competitive advantage they needed to prevent pollution and achieve } \\
\text { environmentally-sustainable economic development, and to better attract and retain the next } \\
\text { generation of employees } \\
\text { Metropolitan Detroit is still in the early stages of responding to the sustainability paradigm } \\
\text { shift, with businesses providing key leadership through operational programs like ISO } 14000 \text {, } \\
\text { ISO 9000, "Design for Environment", Responsible Care } \text {, and others } \\
\text { sustainability in management programs and day-to-day operations }\end{array}$ \\
\hline
\end{tabular}

During the early European settlement years, settlers, like Native Americans before them, had a close relationship to the Detroit River through "ribbon farms" that allowed each property owner access to the riverfront and the freshwater so necessary for human, wildlife, and plant survival. But this close human relationship with the river began to diminish as Detroit developed into a leading center of commerce and trade. Increased commercial activity and trade in Detroit soon led to industrial development. Surrounded by a plethora of untapped natural resources and afforded competitive advantage through water and rail transportation, Detroit turned iron from Lake Superior's Mesabi Range into stoves and railcars, and 
eventually cars by the millions [17]. Indeed, by 1914 Detroit was making half the country's cars. By the middle of the 20th century one in six American jobs were connected to the automobile industry and the Motor City was its epicenter [17]. It should be no surprise that Detroit reached the apex of its population growth in 1950 with nearly 1.9 million people.

Through Detroit's human population growth and industrial expansion, the Detroit River became one of the most polluted rivers in the United States and Detroit residents further lost connection to their river. The Detroit River was clearly perceived as a working river that supported commerce and technological progress [18]. This pollution peaked in the 1960s with: the Detroit River's major tributary, called the Rouge River, catching on fire in 1969 due to oil pollution; major waterfowl kills due to oil pollution; contamination of fish and wildlife with chemical pollutants like mercury, PCBs (i.e., industrial organochlorine compounds), and the pesticide DDT; water contamination by raw sewage; and more [18]. Like many other large North American cities, the Motor City made the Detroit River its back door, with businesses facing inland and away from the river. Compounding the problem, Detroit became indifferent to the water pollution that was perceived as just part of the cost of doing business.

Since the $1950 \mathrm{~s}$, Detroit has experienced considerable loss of population (over a $60 \%$ decline since 1950) and industry, rising unemployment, increased cost of living, decreased access to city services, and increased crime. To many, it became the "poster child" of the Rust Belt. This industrial decline, population emigration, loss of jobs, and concomitant other socio-economic problems culminated in 2013 when Detroit became the largest city in the United States to ever go through bankruptcy.

It was also during the 1960s that the Detroit River was considered one of the most polluted rivers in North America because of its long history of industrial and urban development that led to unsustainable human use and abuse of this ecosystem [19]. Oil pollution was causing winter waterfowl kills, phosphorus pollution was causing accelerated eutrophication, municipalities and industries were causing violations of water quality standards, toxic substances were causing reproductive impairment in wildlife and causing fish consumption advisories, and land use practices were destroying wetlands [19]. Over 40 years of pollution prevention and control have resulted in substantial environmental improvements since the 1960s [18], including:

- Substantial reductions in oil discharges and spills have occurred, and winter duck kills due to oil pollution have been eliminated;

- Billions of dollars have been spent on municipal wastewater treatment and virtually all plants in Michigan and Ontario are achieving secondary treatment with phosphorus removal;

- There has been a 90\% decline in phosphorus concentration and loading from the Detroit Wastewater Treatment Plant (one of the largest in the U.S.);

- Between 1960 and 2005 there has been a 65\% reduction in untreated combined sewer overflow volume from communities in southeast Michigan;

- Over 4000 tonnes/day of chloride loadings to the Detroit River were eliminated due to industrial process changes between the 1960s and 1980s;

- Substantial reductions in contaminants in fish have occurred $(50 \%-85 \%$ decline in mercury contamination and 70\%-90\% decline in DDT contamination), yet health advisories remain in effect;

- Substantial reductions in contaminants in herring gull (Larus argentatus) eggs (90\% decline in DDE - a breakdown product of the pesticide DDT and 85\% decline in PCBs); 
- Nearly one million cubic meters of contaminated sediment have been remediated at a cost of over $\$ 154$ million (U.S.); and

- PCBs levels in Lake Erie sediment have declined by approximately 50\% and mercury levels have declined by about $70 \%$ since the 1970 s.

Today, this environmental cleanup and revival of the Detroit River has led to one of the most remarkable ecological recovery stories in North America with the return of balk eagles, peregrine falcons, osprey, lake sturgeon, lake whitefish, walleye, wild celery, mayflies, beaver, and more (Table 2).

Table 2. Evidence of the return of sentinel wildlife species in the Detroit River watershed, representing one of the most remarkable recovery stories in North America [18].

\begin{tabular}{|c|c|}
\hline Species & Evidence of Recovery \\
\hline $\begin{array}{l}\text { Bald Eagle (Haliaeetus } \\
\text { leucocephalus) }\end{array}$ & $\begin{array}{l}\text { There was nearly complete reproductive failure of the bald eagle population by the } \\
\text { mid-1970s. In 2013, there were } 22 \text { active nests in the watershed of the Detroit River } \\
\text { International Wildlife Refuge after a } 25 \text {-year absence. }\end{array}$ \\
\hline $\begin{array}{l}\text { Peregrine Falcon (Falco } \\
\text { columbarius) }\end{array}$ & $\begin{array}{l}\text { The peregrine falcon population was decimated by the } 1950 \text { s and reintroduced in } \\
\text { Detroit in } 1987 \text {. Reproductive success steadily increased to } 10 \text { young fledged in } 2005 \text {. }\end{array}$ \\
\hline Osprey (Pandion haliaetus) & $\begin{array}{l}\text { In } 2009 \text { a pair of osprey built a nest in a Refuge unit off the mouth of the Detroit } \\
\text { River, representing the first time osprey had successfully nested in Wayne County } \\
\text { (where Detroit resides) since the 1890s. }\end{array}$ \\
\hline $\begin{array}{l}\text { Lake Sturgeon (Ascipenser } \\
\text { fluvescens) }\end{array}$ & $\begin{array}{l}\text { No lake sturgeon spawning was documented in the Detroit River between } 1970 \text { and } \\
\text { 1999. Then in 2001, lake sturgeon spawning was documented for the first time in } \\
30 \text { years. }\end{array}$ \\
\hline $\begin{array}{l}\text { Lake Whitefish (Coregonus } \\
\text { clupeaformis) }\end{array}$ & $\begin{array}{l}\text { In } 2006 \text {, lake whitefish spawning was documented in the Detroit River for the first } \\
\text { time since } 1916 \text {. }\end{array}$ \\
\hline Walleye (Sander vitreus) & $\begin{array}{l}\text { In the } 1970 \text { s, the walleye population was considered to be in crisis by the Lake Erie } \\
\text { Committee of the Great Lakes Fishery Commission. Today, the Detroit River is } \\
\text { considered part of the "walleye capital of the world" with annual tournaments } \\
\text { offering } \$ 500,000 \text { (U.S.) in prize money. }\end{array}$ \\
\hline $\begin{array}{l}\text { Wild Celery (Vallisneria } \\
\text { americana) }\end{array}$ & $\begin{array}{l}\text { Based on monitoring of historically important duck feeding locations in the lower } \\
\text { Detroit River, wild celery tuber abundance declined } 72 \% \text { between } 1950-1951 \text { and } \\
1984-1985 \text {, and then increased } 200 \% \text { between } 1984-1985 \text { and } 1996-1997 \text {. }\end{array}$ \\
\hline Mayflies (Hexagenia spp.) & $\begin{array}{l}\text { Riverwide monitoring has documented an increase in mayfly nymph abundance } \\
\text { from less than } 10 \text { nymphs per } \mathrm{m}^{2} \text { in } 1968 \text { to } 20 \text { or more nymphs per } \mathrm{m}^{2} \text { in } 1999 \text { and } \\
2004 \text { (the two most recent years sampled). }\end{array}$ \\
\hline $\begin{array}{l}\text { American Beaver (Castor } \\
\text { canadensis) }\end{array}$ & $\begin{array}{l}\text { Beaver were extirpated from the region during the Fur Trade Era. During the height } \\
\text { of oil pollution in the } 1940 \mathrm{~s}-1970 \mathrm{~s} \text {, beaver could not have survived in the Detroit } \\
\text { River because oiled fur becomes matted and they lose their ability to trap air and } \\
\text { water to maintain body temperatures. As of } 2013 \text {, beaver had been reported at six } \\
\text { locations in the Detroit River watershed. }\end{array}$ \\
\hline
\end{tabular}

There is now also evidence of revival in metropolitan Detroit with many new jobs, new housing projects and developments, and increased community pride. Two case studies of how metropolitan Detroit is today creating gathering places for people and wildlife along the Detroit riverfront to foster sustainable redevelopment are presented: the DRIWR and the Detroit RiverWalk. These two case studies were chosen because of the nature and extent of their use of public-private partnerships, their high 
visibility, the impact they are having on the Detroit Metropolitan Area, and their potential to showcase and catalyze additional sustainability projects in the spirit of continuous improvement. These projects were also chosen because of their potential to change the perception of the Detroit River from one of a polluted river in the Rust Belt to one that provides many beneficial uses and quality of life benefits, and to change the perception of the metropolitan region from one of Rust Belt city to one that fosters sustainability through public-private partnerships. The data and information on these two case studies were collected over the past 15 years through personal involvement in establishing and managing the DRIWR and Detroit Riverfront Conservancy. All data and information were evaluated in an adaptive management context where assessments are made, priorities are set, and actions taken in the spirit of continuous improvement for long-term sustainability.

\section{Detroit River International Wildlife Refuge}

Again, during the 1960s the Detroit River was considered one of the most polluted rivers in North America and today the cleanup and recovery of the Detroit River represent one of the most remarkable ecological recovery stories in North America [19]. This 40-year cleanup and recovery of the Detroit River laid the foundation for the establishment of the DRIWR - the only international one in North America.

In 2000, a conservation vision for the lower Detroit River ecosystem was drafted by a group of Canadian and U.S. conservationists and scientists that called for the creation of an international wildlife refuge [20]. In 2001, the Detroit River International Wildlife Refuge Establishment Act was signed creating the refuge on the U.S. side (Figure 1). Canada later followed with the creation of the Western Lake Erie Watersheds Priority Natural Area that would complement and reinforce U.S. efforts for the international wildlife refuge under the leadership of Essex Region Conservation Authority.

The DRIWR extends along the shoreline of the Detroit River and western Lake Erie, and focuses on conserving, protecting, and restoring habitats for 30 species of waterfowl, 117 kinds of fish, and over 300 species of birds [20]. The Detroit River and western Lake Erie contain extensive feeding and resting habitats for waterfowl. For example, over 300,000 diving ducks stop each year to rest and feed on beds of wild celery in the lower Detroit River during their fall migration from western Canada to the east and south. The North American Waterfowl Management Plan has identified the Detroit River as part of one of 34 Waterfowl Habitat Areas of Major Concern in the United States and Canada. In addition, marshes along the lower Detroit River and western Lake Erie have been declared part of a Regional Shorebird Reserve by the Western Hemispheric Shorebird Reserve Network. The Detroit River and western Lake Erie have one of the highest diversities of fish and wildlife in the Great Lakes. This biodiversity led Environment Canada and U.S. Environmental Protection Agency to identify the Detroit River-Lake St. Clair ecosystem and one of 20 Biodiversity Investment Areas in the Great Lakes Basin Ecosystem. The lower Detroit River has been identified as an Important Bird Area by National Audubon Society. The DRIWR is not only the only international one in North America and one of only a few truly urban refuges charged with bringing conservation to cities. The Detroit River also has the distinction of being the only international heritage river system in North America. Outdoor recreation in these natural resources contribute tens of millions of dollars to the local economy through public uses like fishing, hunting, wildlife observation, environmental education, kayaking, photography, interpretation, and more. 


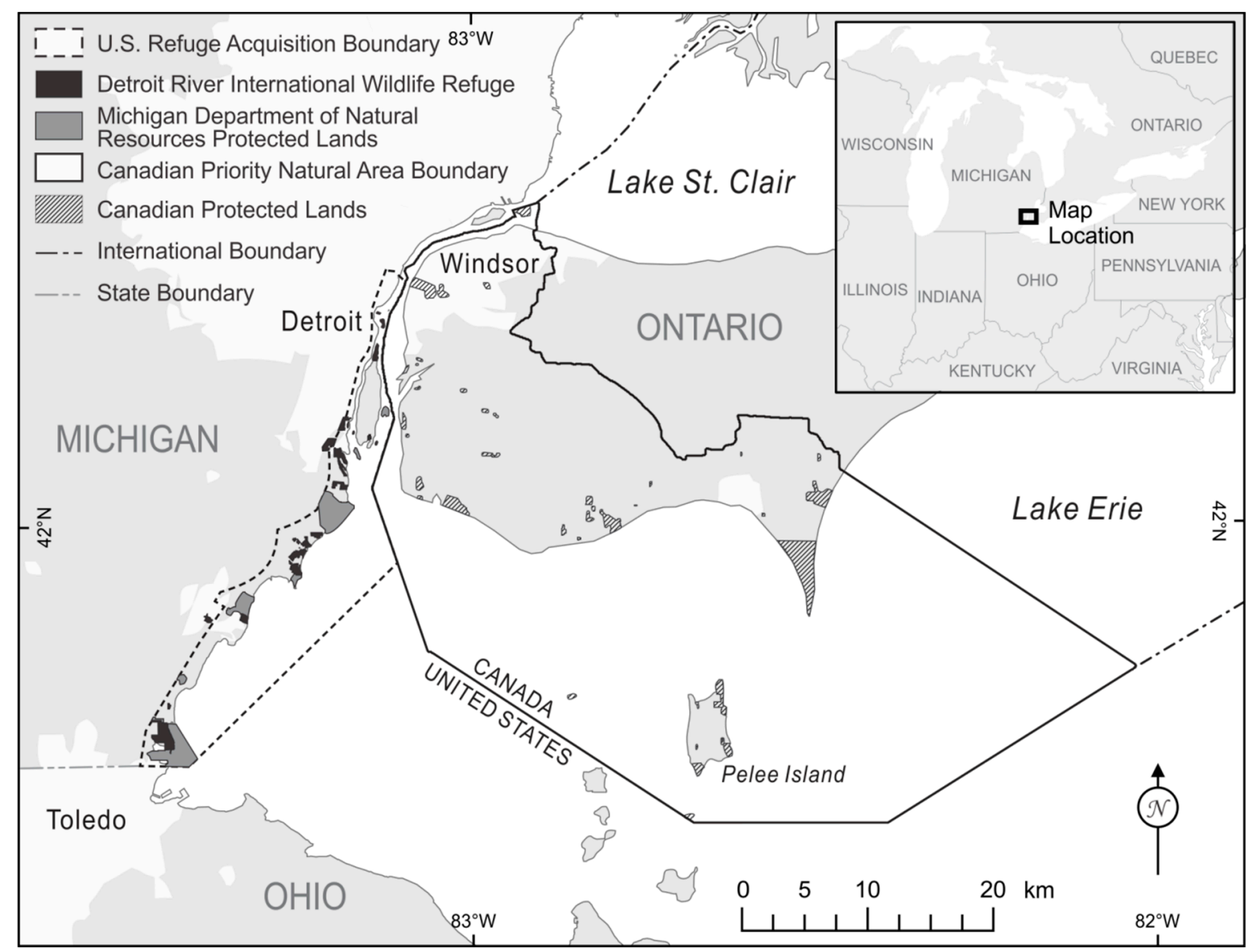

Figure 1. U.S. refuge acquisition boundary and Canadian Western Lake Erie Watersheds Priority Natural Area boundary that are being used to build the DRIWR.

The institutional framework for the DRIWR is presented in Figure 2. Primary leadership for building and managing the refuge on the U.S. and Canadian sides has been provided by the U.S. Fish and Wildlife Service under its National Wildlife Refuge System and the Essex Region Conservation Authority in Ontario, respectively. Over 200 community, governmental, nongovernmental, and business partners have been involved, including a nonprofit friends group called International Wildlife Refuge Alliance.

Cooperative management agreements are entered into with industries and other organizations to manage lands for conservation purposes. A Memorandum of Understanding has been signed between the U.S. Fish and Wildlife Service and the Michigan Department of Natural Resources to guide cooperative conservation within the U.S. portion of the Detroit River and western Lake Erie. The International Wildlife Refuge Alliance works with the refuge staff to build capacity, using a series of committees and special teams. The State of the Strait Conference Steering Committee is binational in scope and make-up, whereas Detroit River Hawk Watch Advisory Committee, Grosse Ile Nature and Land Conservancy, and the Cooperative Weed Management Area are focused just on U.S. initiatives.

On the Canadian side, federal, provincial, regional, local, and nongovernmental partners work through the Western Lake Erie Watersheds Priority Natural Area. U.S. Fish and Wildlife Service and Essex Region Conservation Authority have also signed a Memorandum of Understanding to work collaboratively on transboundary conservation and outdoor recreational initiatives. Clearly, this institutional framework and transboundary cooperation will continue to evolve and improve consistent with an adaptive management philosophy. 


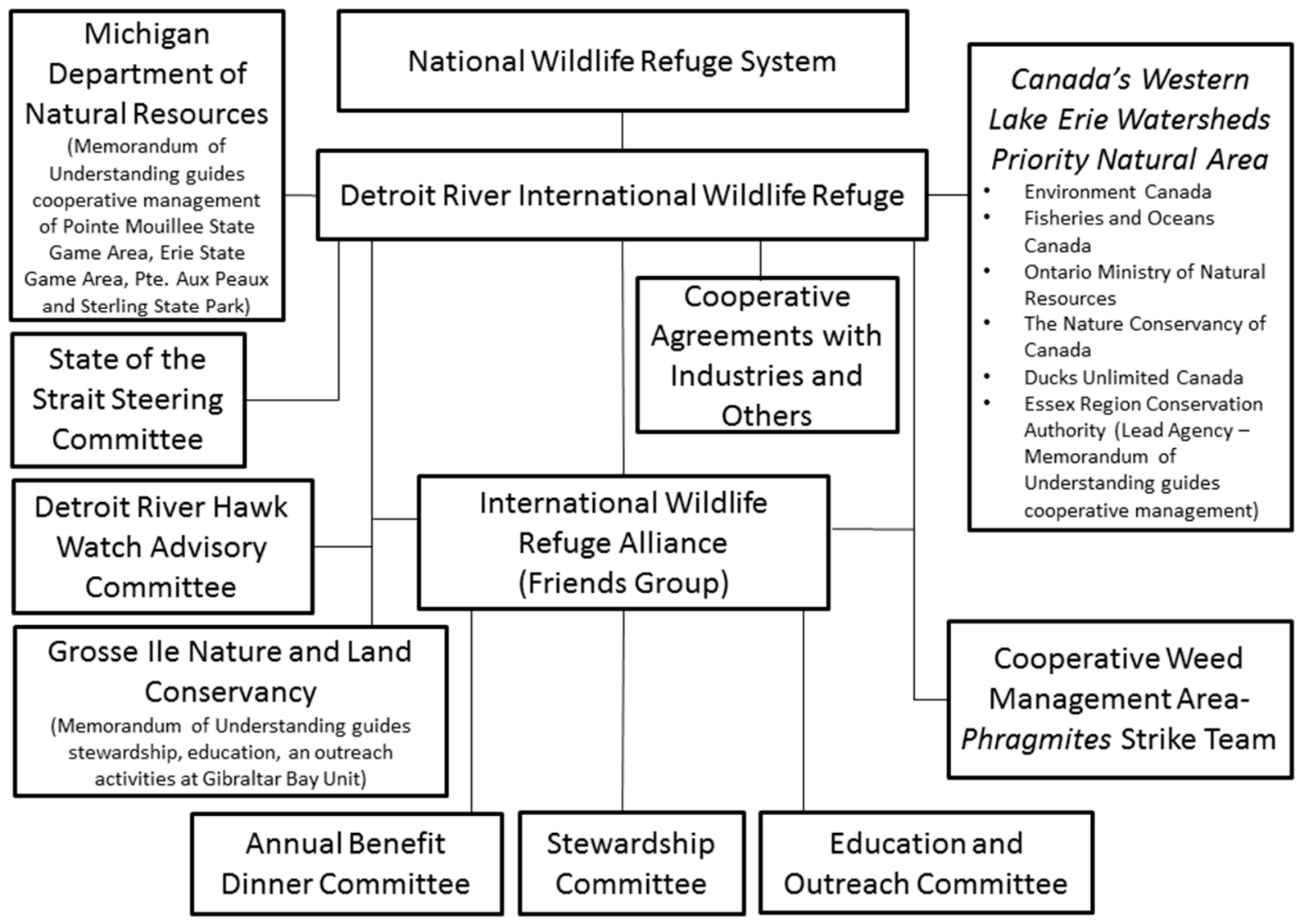

Figure 2. An institutional framework for managing the DRIWR [18].

To date, 1536.6 ha (3797 acres) of Essex Region Conservation Authority lands and 397 ha (981 acres) of City of Windsor lands have been added to a Canadian registry of lands for the refuge, and 3195.8 ha (7897 acres) of Michigan Department of Natural Resources lands have been added to a U.S. registry of lands that already includes 2360.9 ha (5834 acres) of lands owned and/or cooperatively managed by U.S. Fish and Wildlife Service (Figure 1). When totaled between Canada and U.S., 7490.3 ha $(18,509)$ acres of land in southwest Ontario and southeast Michigan are now being managed collaboratively for conservation and outdoor recreation in the spirit and intent of the refuge and the 2001 Conservation Vision. The binational goal for the next ten years is to achieve 10,117.1 ha (25,000 acres) of land devoted to conservation and outdoor recreation in southwest Ontario and southeast Michigan — an area with nearly seven million people in a 45-minute drive.

One good example of creating a new gathering place for people and wildlife is the cleanup and restoration of an industrial brownfield into the Refuge Gateway and home of the Refuge's Gold Leadership in Energy and Environmental Design (LEED)-certified visitor center (Figure 3A,B). Owned by Wayne County and cooperatively managed with the U.S. Fish and Wildlife Service, the Refuge Gateway in Trenton, Michigan, USA will serve as a hub for environmental education and outdoor recreational activities, and a model of sustainability. Everything visitors see and do at the Refuge Gateway and visitor center will teach them how to live sustainably. 


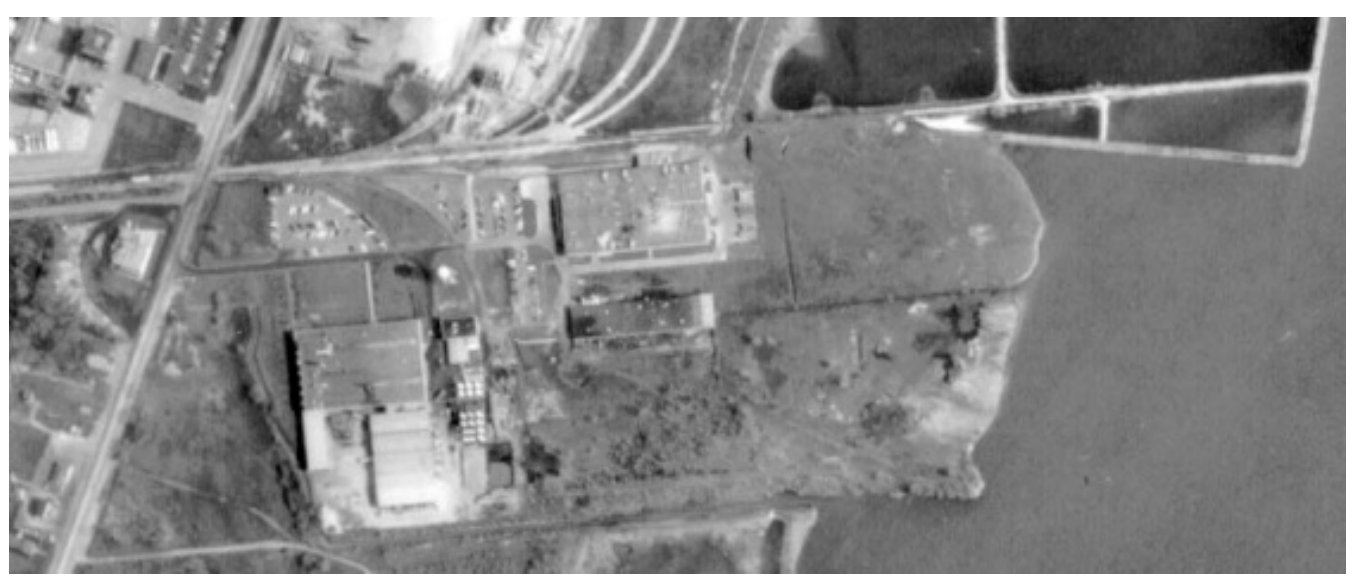

(A)

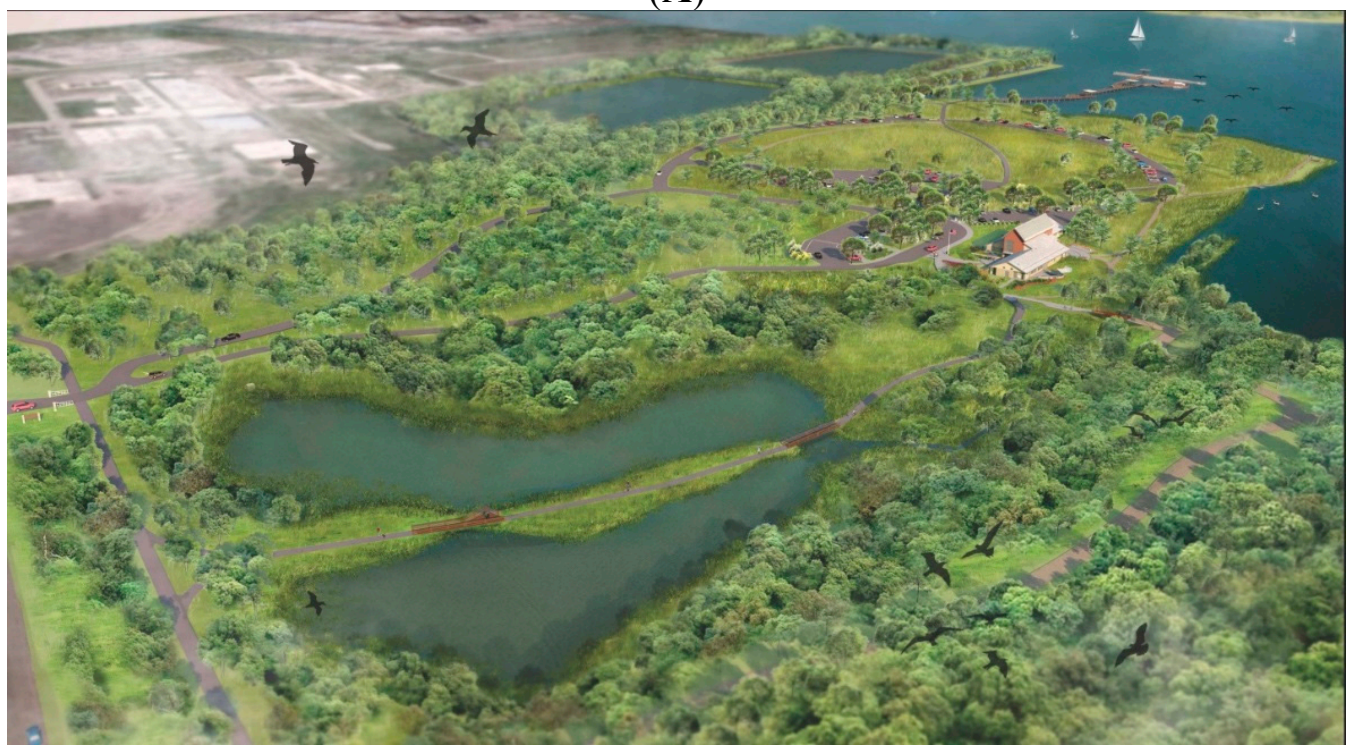

(B)

Figure 3. Aerial photograph of the Chrysler Manufacturing Facility in Trenton, Michigan, 1967 (photo credit: City of Trenton) (A) and Refuge Gateway Master Plan that has guided redevelopment of the site (plan credit: Hamilton Anderson Associates) (B).

For 44 years, this 17.8-ha (44-acre) site was operated as a Chrysler manufacturing facility for brake pad adhesives for automobiles, blended oils, paints, sealers, powdered metal parts, asbestos brake pads, and phenolic brake pistons [21]. This Chrysler Plant was deactivated in 1990 and underwent removal of all above-ground structures. In 1994, Chrysler Corporation and the Michigan Department of Natural Resources entered into a Consent Decree. The Consent Decree is a legally binding document describing Chrysler Corporation's remedial responsibilities, the extent of continuing liability for this site, and long-term due care obligations. On site remedial activities included removal and isolation of both inorganic (i.e., asbestos, arsenic, barium, cadmium, lead, cyanide and thallium) and organic (i.e., benzene, chlorobenzene, methylene chloride, toluene, vinyl chloride and xylene) contaminants.

Essentially, the site was cleaned up at a cost of approximately $\$ 12$ million to meet State of Michigan standards for industrial and commercial use. Pursuant to the Consent Decree, restrictive covenants were placed on five areas of the site totaling approximately 6.1 ha (15 acres). These restrictive covenants limit future activities and use of the 6.1 ha due to subsurface contamination. For example, there can be no 
digging in the capped areas that might release contaminants or exacerbate environmental problems. Restrictive covenants remain in effect in the transfer of the property to any future owner.

The site sat vacant as an industrial brownfield for 12 years before Wayne County acquired the site in 2002 for development as the Refuge Gateway, in partnership with the U.S. Fish and Wildlife Service and others [21]. In 2004, Wayne County completed a master plan to guide redevelopment and ensure that the Refuge Gateway would be a model of sustainable redevelopment that supported public uses like fishing, hunting, kayaking, hiking, environmental education, and more. All cleanup and restoration activities were completed in 2012, including:

- cleanup and capping of contaminated lands;

- daylighting a creek and constructing a retention pond and emergent wetland to treat storm water prior to discharge to the Detroit River;

- restoring coastal wetland, riparian buffer, and upland habitats; and

- constructing two roads, hiking/biking trails, and a kayak/canoe landing to offer wildlife-compatible public uses that allow visitors to experience this internationally-recognized natural resource.

Quantitative restoration achievements included: restoring of 6.5 ha (16 acres) of wetlands in a river that has lost $97 \%$ of its coastal wetland habitat; controlling invasive Phragmites along $4 \mathrm{~km}$ of shoreline; restoring of 10.1 ha (25 acres) of upland buffer habitat; and controlling other invasive species on 20.2 ha (50 acres) of upland habitat [21].

Of particular interest is that the Refuge Gateway is located adjacent to the Refuge's 165.9-ha (410-acre) Humbug Marsh Unit (Figure 4). Back in the mid-1990s, a developer purchased Humbug Marsh with the intent of building a subdivision, a marina, a golf course, a bridge to Humbug Island to accommodate homes, and more. Citizens spoke out in opposition and fought for 10 years to help save it from development. This public support was a key catalyst in establishing the DRIWR.

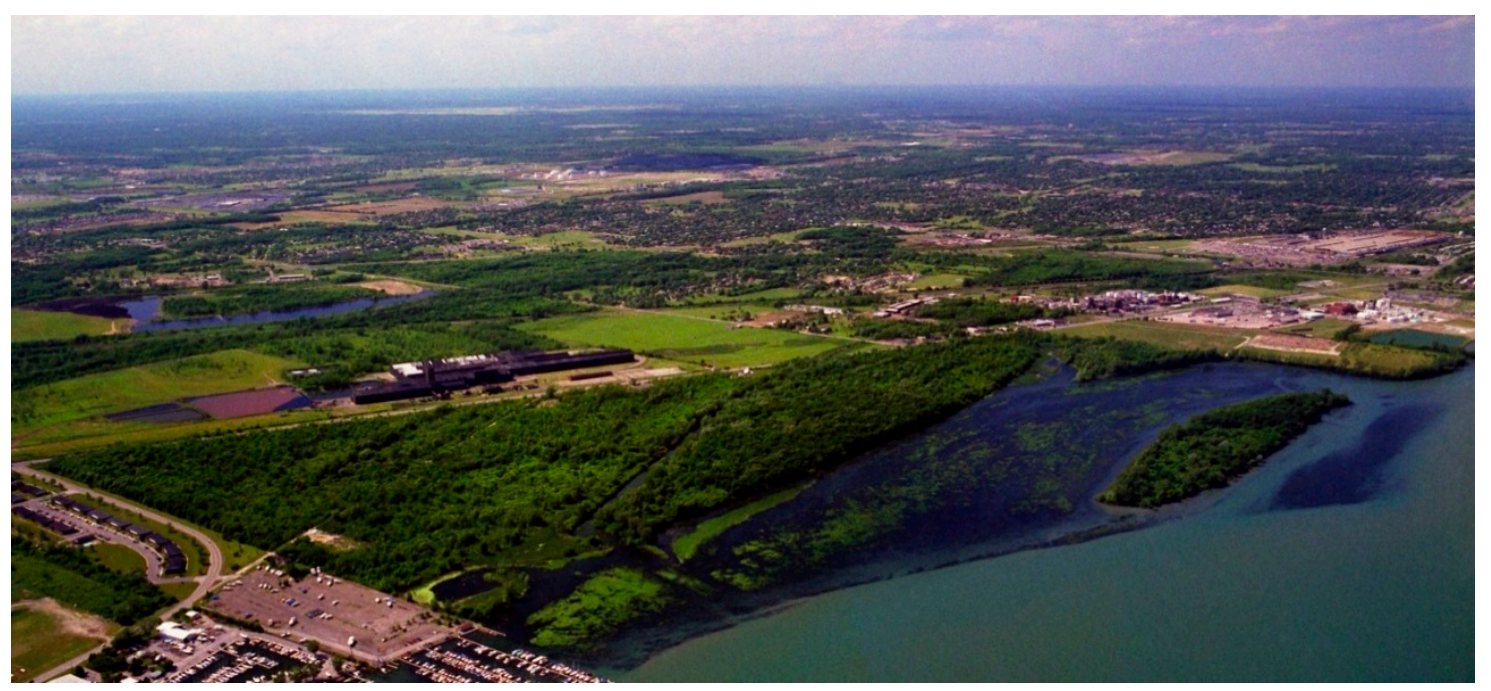

Figure 4. An aerial photograph of Humbug Marsh-Michigan's only "Wetland of International Importance" designated under the Ramsar Convention (photo credit: Visual Image Productions). 
Following the preservation of Humbug Marsh in 2004, the Michigan Department of Natural Resources and Environment, and the U.S. Fish and Wildlife Service spent nearly three years compiling scientific data on Humbug Marsh that were used as the rationale for obtaining a "Wetland of International Importance" designation under the international Ramsar Convention. In 2010, Humbug Marsh received this designation from the international Ramsar Convention. There are over 2000 such Ramsar designations worldwide, 37 in the United States, and only one in Michigan-Humbug Marsh. The Ramsar Convention is an international treaty that was signed in Ramsar, Iran in 1971 that provides a framework for voluntary international protection of wetlands. Humbug Marsh is considered an internationally important wetland because of its ecological importance in the Detroit River corridor and the Great Lakes Basin Ecosystem. Indeed, the Michigan Natural Features Inventory has ranked this community as globally imperiled. It serves as vital habitat for 51 species of fish, over 90 species of plants, 154 species of birds, seven species of reptiles and amphibians, and 37 species of dragonflies and damselflies. Examples of unique species include:

- bald eagles protected in the U.S. by the Bald and Golden Eagle Protection Act;

- the Prothonotary Warbler (Protonotaria citrea) that is listed as "Michigan Species of Special Concern" and "Species of Greatest Conservation Need" by Michigan's Wildlife Action Plan;

- two dragonfly species (i.e., Elusive Clubtail—Stylurus notatus and Russet-tipped Clubtail—Stylurus plagiatus) that are listed as "Michigan Species of Special Concern" and "Species of Greatest Conservation Need" by Michigan's Wildlife Action Plan;

- the eastern fox snake (Elaphe vulpine gloydi) that is designated as a "Threatened Species" in Michigan;

- a native Michigan orchid called Oval Ladies'-Tresses (Spiranthes ovalis) that is designated as a "Threatened Species" in Michigan and that has, on a scale of 0 to 10 , a "coefficient of conservation" of 9 , meaning that this plant species is likely to occur in high quality landscapes relatively unaltered from those of pre-settlement times; and

- a rare sedge called the Hairy-Fruited Sedge (Carex Trichocarpa) that is listed as a "special concern" species in Michigan and has been given a "coefficient of conservation" of 8 .

This project has been described as transformational for the region by restoring an industrial brownfield into high quality wildlife habitat that supports public uses. Indeed, it is the only project in the world to successfully clean up and restore an industrial brownfield sufficiently to serve as an ecological buffer for a Ramsar "Wetland of International Importance".

\section{Detroit RiverWalk}

As recently as the early-2000s, a considerable portion of Detroit's waterfront land between the MacArthur Bridge to the 397-ha island park called Belle Isle and the Ambassador Bridge to Canada was either abandoned buildings, underutilized street parking lots, material storage piles, or cement silos that prohibited access to the Detroit River. For over a century city planners identified the highest and best use of this land to be "industrial" because of obvious revenue returns. Detroit was an industrial town and it had a working riverfront that supported industry and commerce. However, times had changed. There were fewer people and industries, and much underutilized and undervalued riverfront land. Detroiters had long 
lost their connection to the Detroit River and they wanted to improve public access to it and redevelop it in a fashion that would improve quality of live, catalyze economic development, and help change the perception of Detroit from that of a Rust Belt city to one that is actively engaged in sustainable redevelopment.

It should be noted that there were numerous historical attempts in Detroit to create a more open and accessible riverfront, starting with Detroit Mayor Hazen Pingree who, during his four-year term staring in 1889, proposed a plan for an extended park along Detroit's riverfront. However, all of them failed.

In more recent years it is fair to say that there was no single catalytic moment that created the Detroit RiverWalk. Rather, it was a series of events/initiatives that gradually brought a more publicly-accessible and environmentally-friendly riverfront dream to reality. One early initiative was a 1976 study titled "The Land and The River" undertaken by an Interagency Task Force for Detroit/Wayne County Riverfront Development that inventoried riverfront lands and took stock of future possibilities beyond an industrial waterfront. As a result of that study, the City of Detroit developed a Linked Riverfront Parks Plan in 1979-1980 as a blueprint for creation of a system of riverfront parks linked by pedestrian trails. In many respects, that Linked Riverfront Parks Plan was the early foundation upon which today's Detroit RiverWalk is being built.

Another key moment in riverfront history was when the late Peter Stroh, a fourth generation executive of the Stroh Brewing Company in Detroit, purchased the former World Headquarters of Parke Davis and Company in 1979 for mixed use redevelopment as Stroh River Place. The Stroh River Place campus includes 15 separate buildings that were converted into offices, retail, and housing. The flagship of the Stroh River Place campus is 300 River Place, a 46,452 $\mathrm{m}^{2}$ (500,000 square foot), multi-tenant general office and retail building that includes one of Detroit's premier restaurants called The Rattlesnake Club. This clearly was instrumental in laying the foundation for the Detroit RiverWalk and provided an early example of the unique role of business. Other planning initiatives were undertaken over time that built momentum. Then in 2001 four significant things happened that provided another foretaste of a riverfront greenway:

- General Motors completed a \$500 million renovation of its World Headquarters (called the Renaissance Center) and switched the building front door from Jefferson Avenue (facing inland) to one facing the Detroit River with the construction of a five-story glass atrium called the Winter Garden, laying the foundation for a $\$ 50$ million investment by The Kresge Foundation in creating a riverfront greenway;

- Community Foundation for Southeast Michigan launched its Greenways Initiative that had raised \$25 million to be given away in grants to communities to help make match requirements on federal and state greenways grants;

- United Auto Workers and General Motors opened a $6039 \mathrm{~m}^{2}$ (65,000 square foot) education and training center on the Detroit riverfront called the UAW-GM Training Center; and

- Detroit celebrated its 300th anniversary that included restoration of Campus Martius Park as its legacy project of Detroit 300 and placement of an Underground Railroad Monument on the riverfront.

Together, these four significant developments gave further traction to the desire for a connected riverfront greenway and gave confidence to the City of Detroit to bring key stakeholders together to create an organization that would lead the effort.

Based on past experiences with riverfront planning, Detroit wanted to make sure that any new vision or plan for the riverfront had the support of a broad diversity of the people living in the Detroit area and 
the many stakeholder groups that would impact or be impacted by a transformed riverfront. In 2002, Detroit's Mayor assembled an East Riverfront Study Group made up of 34 key people representing a broad range of interests and charged them with developing a revitalization strategy for Detroit's east riverfront. Organizers did not want a protracted planning process so they commissioned the group to report back in 90 days.

The first task at hand was to reach agreement on a compelling vision for a revitalized riverfront. After much input and debate, the following vision was agreed to:

The historic Detroit River is a gathering place for Detroiters, their families, friends, and visitors-a place where people want to live, work, and play. The riverfront illustrates our ability to provide stewardship of our environment, confirms our ability to connect and care for our people and channels sustainable economic development for the benefit of all. Our riverfront is transformed and we are recognized as an outstanding global community.

From the outset it was understood that no single organization or entity could do this alone. To manifest this, Study Group members each signed an agreement that every participant would do everything within their power to bring this vision to reality [22].

That same year in 2002, the Kresge Foundation committed \$50 million in a series of challenge grants over a five-year period to help build the Detroit RiverWalk, the largest gift in the history of the Foundation. The Kresge Foundation had its roots in Detroit and wanted to give this transformational project and its stakeholders momentum. The Foundation also stipulated that an endowment would be created to ensure long-term, quality operation, maintenance, and programming.

In 2003, the Detroit Riverfront Conservancy was created as a nonprofit organization to oversee the creation of a beautiful, exciting, safe, accessible, world-class gathering place for all. Its Board of Directors is made up of over 40 key leaders representing a broad cross-section of public and private organizations throughout Michigan, including private property owners, businesses, churches, nongovernmental organizations, foundations, unions, financial institutions, law firms, and more. The primary project leader and Chairperson of the Board of Directors was Matthew Cullen who had a long-standing career at General Motors Corporation as General Manager of Economic Development and Enterprise Services, and more recently as President and Chief Executive Officer at Rock Ventures. Matthew Cullen was instrumental in opening doors when needed, establishing funding partnerships, and serving as the well-recognized public champion for the Detroit RiverWalk.

From the very outset the plan was to build a riverfront greenway called the Detroit RiverWalk from the MacArthur Bridge on the east to the Ambassador Bridge on the west. For practical reasons, the RiverWalk project had to be broken up into phases. The first phase was called the East Riverfront and extended from the MacArthur Bridge to Joe Louis Arena, a distance of nearly six kilometers. The second phase was called the West Riverfront and extended from Joe Louis Arena to the Ambassador Bridge, a distance of approximately $3 \mathrm{~km}$.

Substantial efforts were made to ensure that there was an inclusive planning process, one where all voices were heard and factored into the planning process. For example, the vision was presented and stakeholder input obtained in nearly 100 meetings attended by over 4000 people [22]. Public interest was high and some of the community design workshops attracted over 600 people. The most frequent stakeholder concerns received included: the need to address transportation/access problems; retaining 
the historical heritage of Detroit; ensuring safety and cleanliness; and ensuring meaningful involvement of the local community. There were also numerous obstacles, including private interests that wanted to create a waterfront gambling casino district and the fact that several, existing, waterfront, cement silos were not compatible with the vision of a waterfront gathering place that would benefit all. Through the inclusive planning process it was eventually determined that it would be best to locate three gambling casinos inland and away from the waterfront and that the cement silos would be re-located to an industrial district several kilometers downstream.

Detroit Riverfront Conservancy staff and the Board of Directors worked hard to address all concerns and move forward with a sense of urgency to build the nearly nine kilometer Detroit RiverWalk. In addition to providing residents and visitors with a beautiful and safe place to walk, jog, and ride, the Detroit Riverfront Conservancy continues to serve as a catalyst for economic development. Throughout the entire process, the Conservancy goal was to:

- Develop a collective sense of ownership, accessibility, and responsibility;

- Enhance Detroit's image to emphasize its iconic, international riverfront; and

- Create and maintain an inviting destination for all.

An aggressive development program was undertaken to raise the necessary funds to build, operate, maintain, and program the Detroit RiverWalk. The projected cost of building the East Riverfront portion of the Detroit RiverWalk alone was $\$ 140$ million. In its first ten years of existence, the Detroit Riverfront Conservancy raised over $\$ 120$ million [23]. In addition, a $\$ 60$ million endowment target was set to ensure long-term operation, maintenance, and programming, in perpetuity. By the end of its first ten years, the Detroit Riverfront Conservancy had $\$ 42$ million invested in an endowment to support operations.

The first phase of the Detroit riverfront transformation, called East Riverfront, is $6 \mathrm{~km}$ long and nearly $90 \%$ complete (Figure 5 A,B). It is estimated that nearly three million annual visitors are already using the RiverWalk amenities from Gabriel Richard Park to Joe Louis Arena.

As noted above, the vision statement of the Detroit Riverfront Conservancy called for not only creating a waterfront gathering place for people, but promoting stewardship of the environment. Good Detroit RiverWalk examples of promoting stewardship of the environment and sustainability include:

- Creation of an innovative storm water retention basin in Milliken State Park that captures runoff from adjacent roads and parking lots, and filters it through wetlands before being discharged to the Detroit River;

- Rehabilitation and/or enhancement of shoreline habitat at five locations on the Detroit RiverWalk, including Gabriel Richard Park, Stroh River Place, Mt. Elliott Park, east of the Renaissance Center, and the Wayne County-Detroit Port Authority facility;

- Creation of butterfly gardens and a birding spot, complete with four spotting scopes and an interpretive panel, at Gabriel Richard Park;

- LEED-certification of the pavilion at Mt. Elliot Park;

- Establishment of butterfly gardens at General Motors' Renaissance Center; and

- Wildlife Habitat Council certification of General Motors' Renaissance Center. 


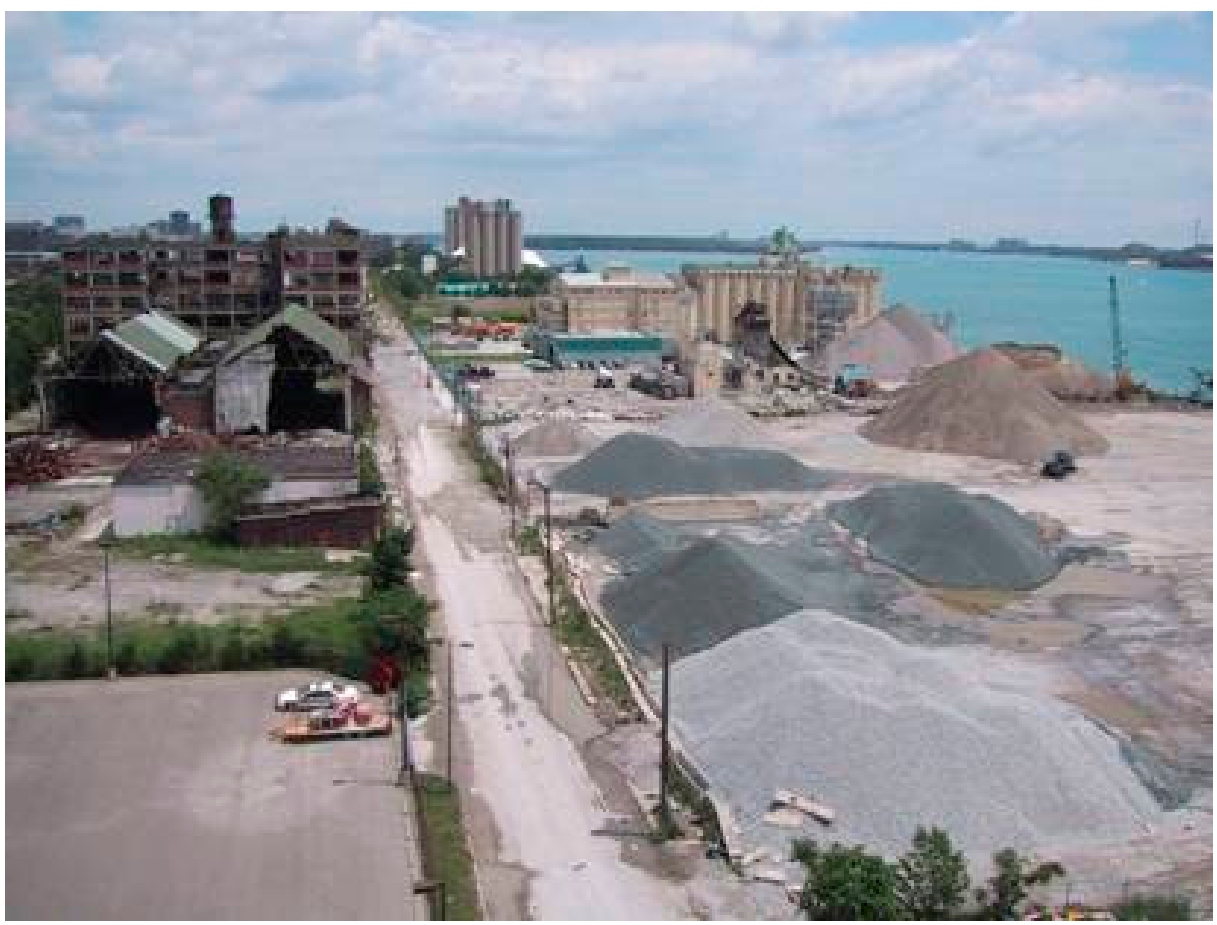

(A)

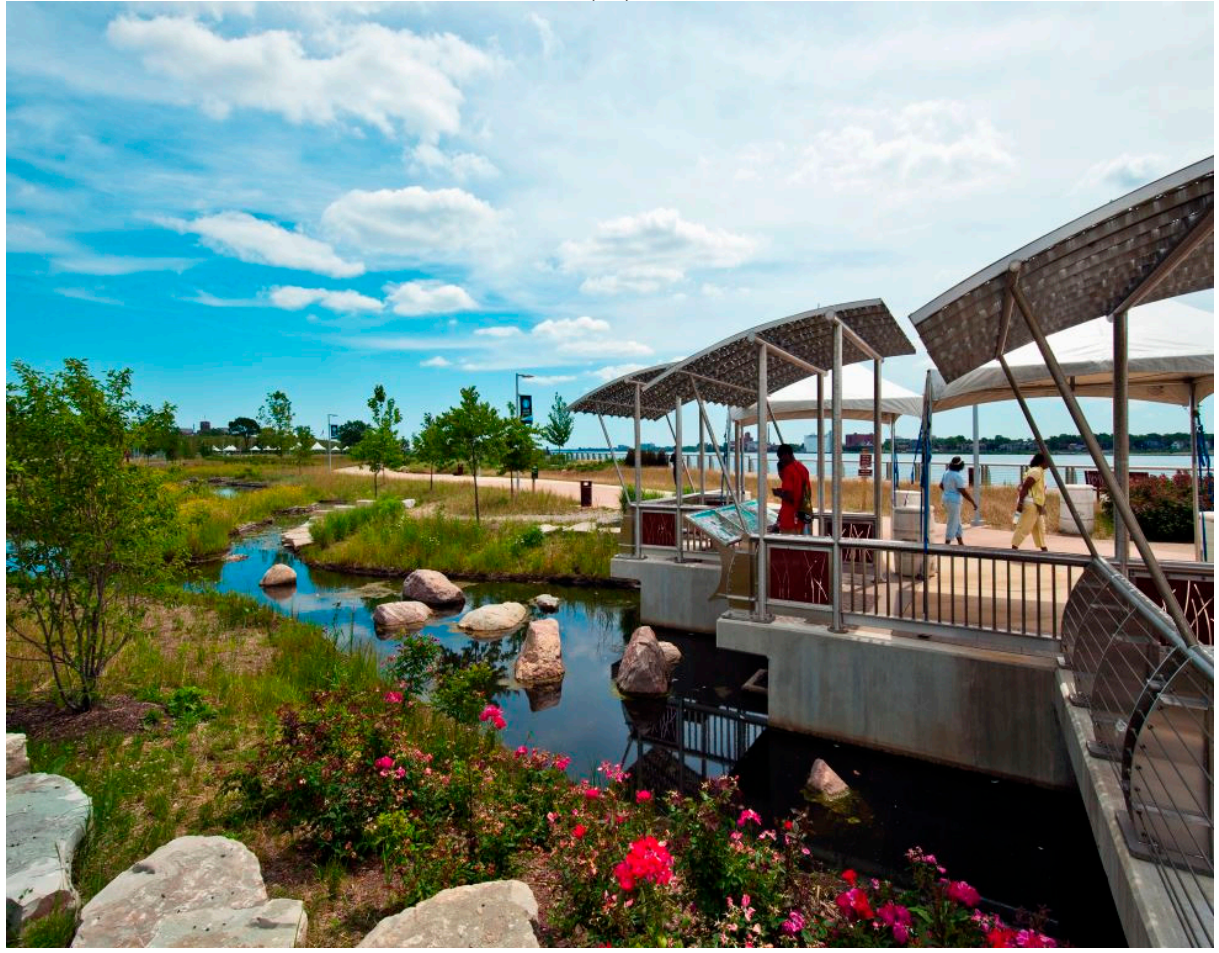

(B)

Figure 5. Detroit waterfront in the early-2000s (A) and the Detroit RiverWalk today (B) (photo credits: A-Detroit Riverfront Conservancy; B-SmithGroupJJR).

The focus of the next phase of riverfront transformation is to provide public access along the $3.2 \mathrm{~km}$ (two-mile) stretch of the West Riverfront from Joe Louis Arena to the Ambassador Bridge. The Detroit Riverfront Conservancy recently completed the 8.1 ha (20-acre) West Riverfront Park at the former Detroit Free Press property as a "green oasis." Visitors now can use three new pathways 
linking the riverfront to West Jefferson Avenue, benches, trash receptacles, and plenty of lush green space for a variety of outdoor activities, including a summer concert series.

The Detroit Riverfront Conservancy continues to work with key stakeholders, including the City of Detroit and private property owners, towards completing a continuous, nearly $9 \mathrm{~km}$ RiverWalk. The amount of progress and community impact are remarkable, considering where it started and the number of obstacles. With its unique outdoor attractions that are helping create a sense of place, the Detroit RiverWalk is attracting nearly three million people and making an enormous civic contribution. In recognition of the significance and impact of the Detroit RiverWalk, the Detroit Riverfront Conservancy was recognized on a global scale in 2014 with an Excellence in the Waterfront Award from The Waterfront Center [24]. Further, the Detroit RiverWalk was identified in 2014 as one of the 10 Best American Riverfronts by readers of USA Today [25].

An economic impact study undertaken for the Detroit Riverfront Conservancy documented that, as of 2012, the investment in building the Detroit RiverWalk was a catalyst for $\$ 1.55$ billion in total public and private sector investment (including the value of contributed land), of which approximately $\$ 639$ million can be directly linked to riverfront improvements [26]. This study concluded that there is potential for an additional \$700-950 million investment in the future [26].

\section{Key Linkages between Detroit and Its Suburbs to Help Foster Sustainability}

An important need for this metropolitan area is to establish more linkages between Detroit and its suburbs to help foster sustainability. The expansion of the automobile industry a century ago caused a population growth spurt that made Detroit the 4th largest city in the United States. By 1950 nearly 1.9 million people lived in Detroit and many were employed in the automobile sector and related industries. By 2014, Detroit's population had declined to 713,777 , of which $82 \%$ were African American.

The emigration of many southern blacks to Detroit for automobile jobs and the emigration of many whites to the suburbs because of racial tensions resulted in the Detroit Metropolitan area becoming one of the most segregated regions in the United States [27]. Clearly, much work is needed to establish linkages between Detroit and its suburbs to help further sustainability.

It has often been said that the water of the Detroit River is what links Detroit and its neighboring communities. For example, the Detroit Water and Sewerage Department supplies potable water to over four million people in Detroit and 127 neighboring communities, and the Detroit River is part of the Great Lakes-St. Lawrence Seaway System that generates over \$34 billion in economic activity on an annual basis [28]. The Detroit River also provides close-to-home, world-class outdoor recreation like fishing in "walleye capital of the world" (over 10 million walleye ascend the river each year to spawn, attracting $\$ 500,000$ walleye tournaments each year), hunting in what Ducks Unlimited has identified one of the top ten U.S. metropolitan areas for waterfowl hunting, boating in an area with one of the highest densities of boat registrations in the U.S., and more.

Three other noteworthy initiatives that link Detroit and neighboring suburban communities to help foster sustainability include: greenways; the Detroit Heritage River Water Trail; and the ByWays to FlyWays Bird Driving Tour. Greenways are linear open spaces, including habitat and trails that link parks, nature preserves, cultural features or historic sites with each other, for recreation and conservation 
purposes. Greenways promote outdoor recreation, catalyze economic development, increase adjacent property values, celebrate history and culture, promote conservation and environmental education, and improve quality of life. In many major urban areas, greenway trails provide an alternative mode of transportation. Since 2001, the Community Foundation for Southeast Michigan raised more than \$26 million from foundations, businesses, and private contributions to help communities build a regional network of greenway trails through its Greenways Initiative. This effort was the first of its kind in the nation that helped communities meet match requirements on federal and state greenways grants when they could not afford to do so. In addition, this innovative funding mechanism created unprecedented momentum for greenway development throughout all communities in southeast Michigan. This \$26 million fund leveraged an additional $\$ 90$ million in public money to catalyze development of hundreds of kilometers of greenways that help connect and unite communities through green infrastructure. It should be noted that the Community Foundation for Southeast Michigan's Greenways Initiative was instrumental in creating the $2.3 \mathrm{~km}$ Diquindre Cut greenway trail that links the Detroit RiverWalk to the largest historic public market district in the U.S. called Eastern Market and to nearby neighborhoods.

Interest in paddle-based recreation like kayaking and canoeing is increasing. To address this interest and meet this demand, the Detroit Heritage River Water Trail was created to provide canoers and kayakers with a paddling experience through waterways that sustained Native Americans, supported the Fur Trade, fostered the Industrial Revolution, and are now heralded as North America's only international wildlife refuge. Paddling opportunities extend some $61.2 \mathrm{~km}$ (38 miles) from Maheras Gentry Park in Detroit at the upper end of the Detroit River to Luna Pier on western Lake Erie in the southern end of Monroe County (Figure 6).

Recently, Michigan residents, through a Michigan Department of Natural Resources survey, identified the Detroit Heritage River Water Trail as one of the "Top 11" Water Trails in Michigan [29]. A user guide is also available for outdoor enthusiasts to plan paddling trips along the Detroit Heritage River Water Trail [30]. This guide offers detailed descriptions of each location, a key feature in designing an outdoor adventure. It also details the newest launch sites, updated information on existing locations, safety suggestions, and resources for local paddling groups. Recommended paddling routes are also highlighted, presenting not only mileage, but water time and possible conditions. Research has shown that this paddle-based recreational industry contributes $\$ 36.1$ billion annually to the U.S. economy [31].

With the Detroit River located at the intersection of the Atlantic and Mississippi Flyways for birds, attracting over 300 species, there are numerous exceptional birding opportunities. With this knowledge, Metropolitan Affairs Coalition, the U.S. Fish and Wildlife Service, Michigan Sea Grant, the International Wildlife Refuge Alliance, Wild Birds Unlimited, and the National Fish and Wildlife Foundation developed a unique "Byways to Flyways" bird driving tour map to promote 27 exceptional birding sites throughout the Windsor-Detroit metropolitan area (Figure 7). Included within these sites are many Important Bird Areas (IBAs) identified by National Audubon Society, two "Wetlands of International Importance" identified under the international Ramsar Convention (i.e., Point Pelee National Park in Ontario and Humbug Marsh in Michigan), several Christmas Bird Count sites, and two internationally recognized hawk watch sites (i.e., Holiday Beach Conservation Area in Ontario and Lake Erie Metropark in Michigan). The economic significance of this outdoor recreational pastime in 2006 was that 71.1 million wildlife watchers in the U.S. spent $\$ 45.7$ billion on their wildlife watching activities around their homes and on trips away from their homes [32]. 


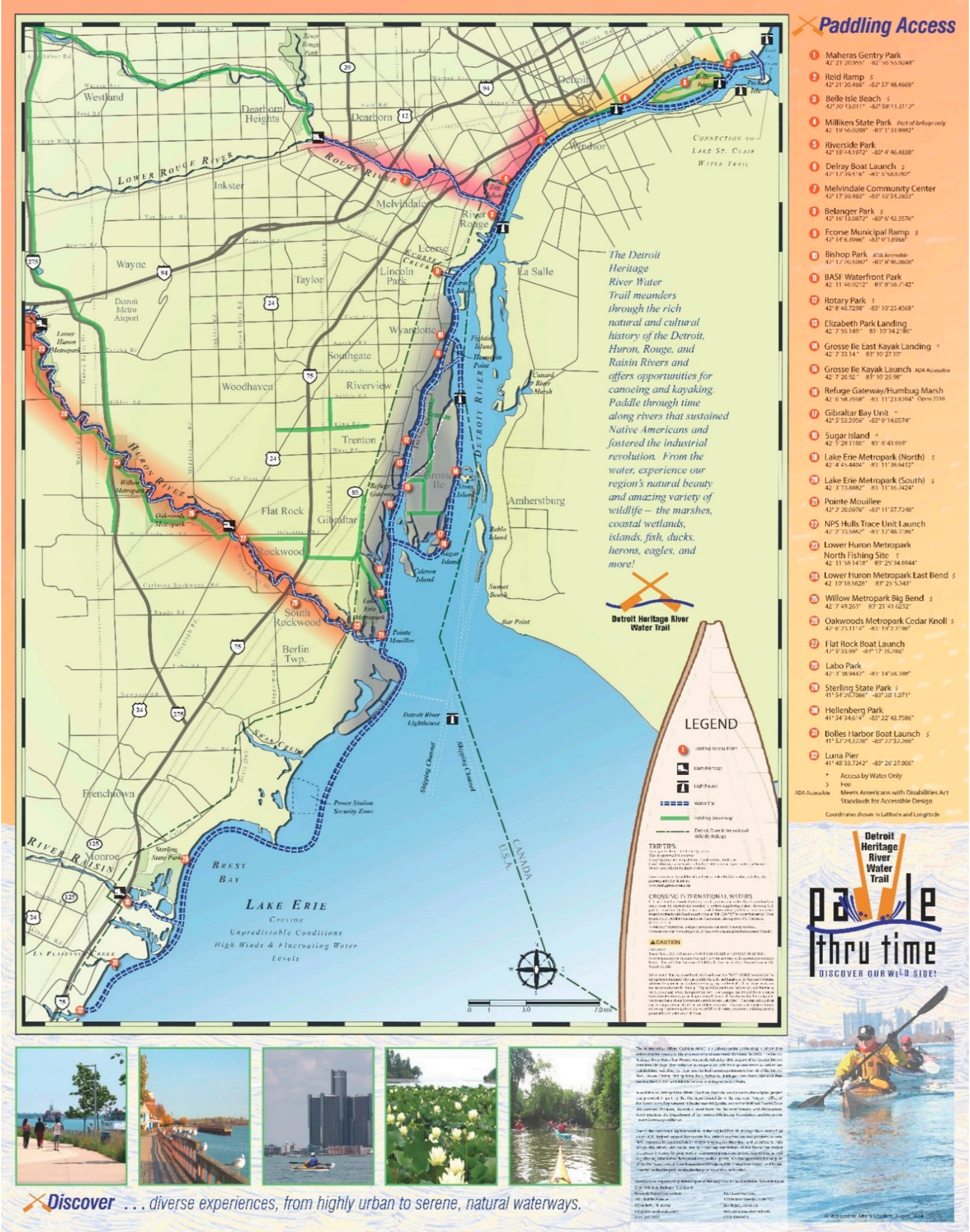

Figure 6. Detroit Heritage River Water Trail along the Detroit River and western Lake Erie (credit: Metropolitan Affairs Coalition). 


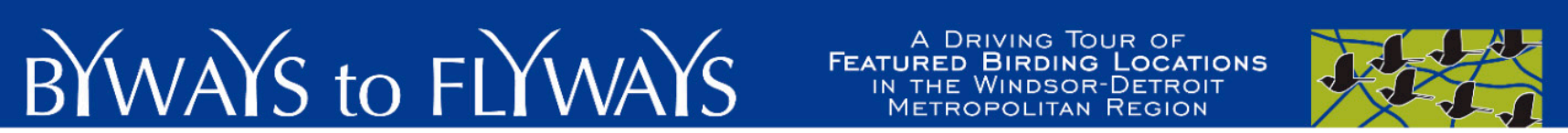

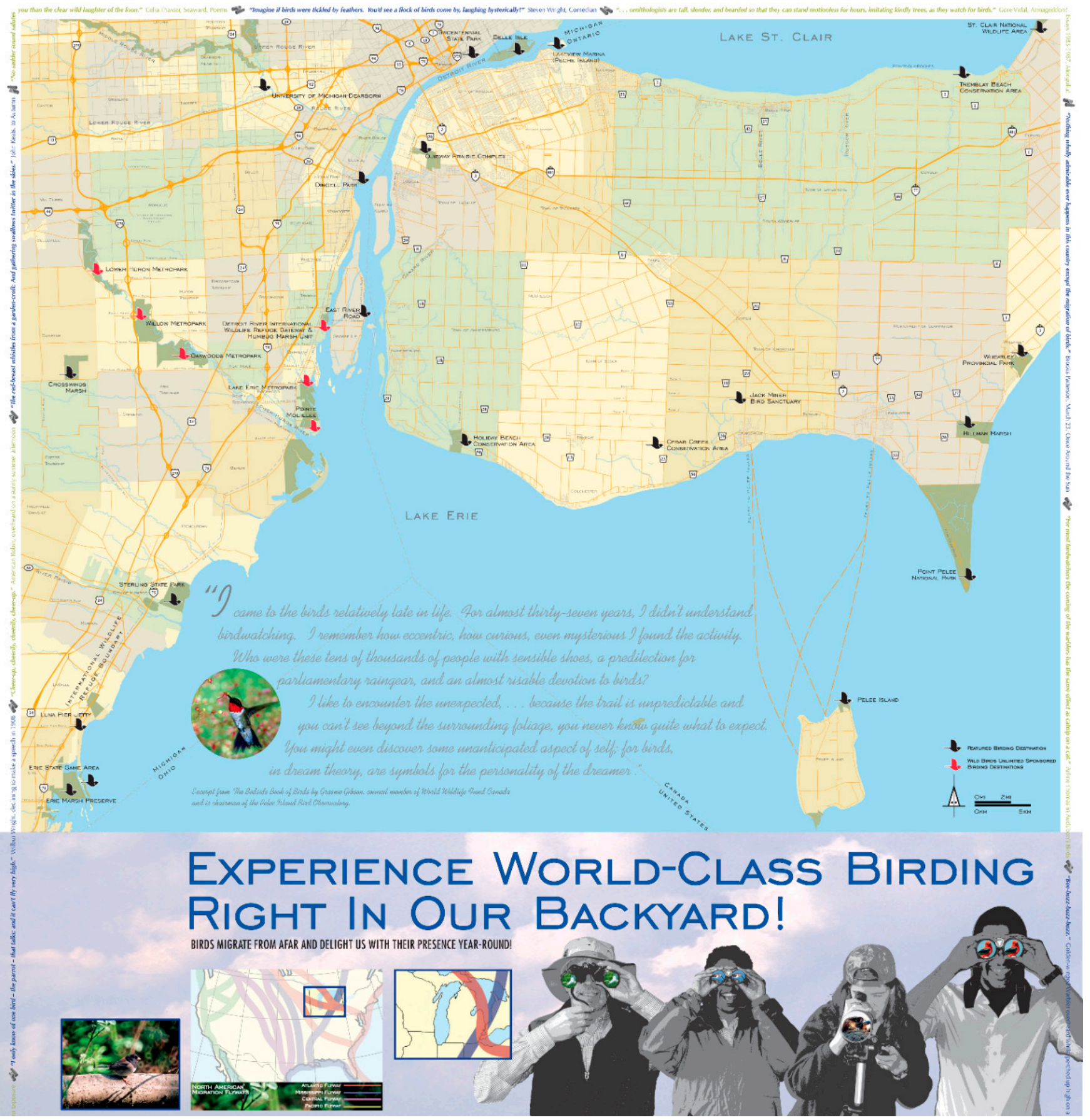

Figure 7. Byways to Flyways bird driving tour map (map credit: Metropolitan Affairs Coalition).

\section{Concluding Remarks}

The DRIWR and Detroit RiverWalk are two compelling examples of how metropolitan Detroit is turning to the Detroit River and embracing it through the creation of gathering places for people and wildlife as part of an effort to help revitalize the city and region, and to help meet the challenge of the sustainability paradigm shift identified in Table 1. Both projects have been described as transformational for the region by restoring and reclaiming industrial brownfields into unique waterfront places for both 
wildlife and people. The DRIWR is not only the only international wildlife refuge in North America, but one of only a few truly urban wildlife refuges in the U.S. The Detroit RiverWalk is one of the largest, by scale, urban waterfront redevelopment projects in the U.S. (9 $\mathrm{km}$ in the heart of downtown Detroit). Both projects provide evidence and give hope that Detroit and its metropolitan region have a brighter and more sustainable future, but clearly more needs to be done.

Internationally, these two projects are helping change the perception of the region from that of a degraded urban area in the Rust Belt characterized by abandoned industrial brownfields, a polluted river, and a Great Lakes pollution hotspot (i.e., the Detroit River is one of 42 Great Lakes Areas of Concern identified by the U.S. and Canada) to one of an international, urban leader in reconnecting people to nature, improving quality of life, showcasing sustainable redevelopment, and enhancing economic development and community pride.

Key lessons learned from these two transformational projects include:

- establish a common vision;

- recruit a well-respected champion;

- ensure broad support from key stakeholder groups;

- establish a core delivery team, focused on outcomes and success;

- build trust and ensure cooperative learning;

- adopt a strategic approach to community engagement, creating a connected community;

- evoke a sense of place; and

- measure and celebrate successes to sustain momentum (Table 3).

Such lessons may by useful to other large urban areas throughout the world in their efforts to reconnect people with natural resources and foster a more sustainable future.

Table 3. Key lessons learned from building the Detroit River International Wildlife Refuge and the Detroit RiverWalk in metropolitan Detroit, Michigan, USA.

\begin{tabular}{|c|c|}
\hline $\begin{array}{c}\text { Key Lessons } \\
\text { Learned } \\
\end{array}$ & Description/Examples \\
\hline $\begin{array}{c}\text { Establish } \\
\text { common vision }\end{array}$ & $\begin{array}{l}\text { A clear and compelling vision is important in any major urban initiative. This vision must be relevant, } \\
\text { appealing, and engaging, and must be a picture that all stakeholders can carry in their hearts and minds [33]. } \\
\text { The visions of building a Detroit RiverWalk to reconnect Detroiters to their international waterfront } \\
\text { and building North America's only international wildlife refuge were clearly unique and compelling, } \\
\text { and strongly supported by all stakeholders. }\end{array}$ \\
\hline $\begin{array}{c}\text { Recruit a } \\
\text { well-respected } \\
\text { champion }\end{array}$ & $\begin{array}{l}\text { It was important to recruit champions who had respect in the community and could establish a broad } \\
\text { coalition and common vision, including government buy-in and an ability to survive changes in } \\
\text { administrations. Matthew Cullen (champion for the Detroit Riverfront Conservancy) had a long-standing } \\
\text { career at General Motors Corporation as General Manager of Economic Development and Enterprise } \\
\text { Services and more recently as President and Chief Executive Officer at Rock Ventures. U.S. } \\
\text { Congressman John Dingell (champion for the DRIWR) was Dean of the U.S. Congress and had served } \\
\text { for } 59 \text { years. Both these individuals were passionate about their respective projects and made the time } \\
\text { in their busy schedules to be project champions and to "open doors" to make things happen. }\end{array}$ \\
\hline
\end{tabular}


Table 3. Cont.

\begin{tabular}{|c|c|}
\hline Learned & Description/Examples \\
\hline $\begin{array}{l}\text { Ensure broad } \\
\text { support from } \\
\text { key stakeholder } \\
\text { groups }\end{array}$ & $\begin{array}{l}\text { Major urban projects need broad support from many stakeholder groups, including key leaders. Such } \\
\text { strong and early support can help establish legitimacy and can help build momentum. In the case of the } \\
\text { Detroit Riverfront Conservancy, substantial early support was provided by The Kresge Foundation ( } \$ 50 \\
\text { million to build the Detroit RiverWalk) and General Motors Corporation (who renovated its World } \\
\text { Headquarters called the Renaissance Center and switched its headquarters front door from facing inland } \\
\text { to facing the Detroit River). In the case of the DRRIW, consistent long-term financial support was } \\
\text { provided by DTE Energy, BASF Corporation, and others. }\end{array}$ \\
\hline $\begin{array}{l}\text { Establish core } \\
\text { delivery team, } \\
\text { focused on } \\
\text { outcomes and } \\
\text { success }\end{array}$ & $\begin{array}{l}\text { A core project delivery team was essential to coordinate among partners, keep on schedule, and fulfil } \\
\text { commitments. If a project required any permits, early efforts were made to ensure that all regulatory } \\
\text { agencies were involved up front in the process to ensure buy-in, support for the project, and timely } \\
\text { review and approval of permits. Both the Detroit Riverfront Conservancy and the DRIWR have } \\
\text { excellent staffs that deliver projects on time, within budget, and with quality. Capacity-building is } \\
\text { achieved by a } 47 \text {-member Board of Directors of the Detroit Riverfront Conservancy and 16-member } \\
\text { Board of Directors of the DRIWR's friends group called the International Wildlife Refuge Alliance. }\end{array}$ \\
\hline $\begin{array}{l}\text { Build trust and } \\
\text { ensure } \\
\text { cooperative } \\
\text { learning }\end{array}$ & $\begin{array}{l}\text { Building the Detroit RiverWalk and DRIWR have clearly required partnerships built on trust and } \\
\text { respect. Partnerships are all about relationships built on trust and respect. Such processes require an } \\
\text { open and inclusive decision-making process, clear roles and responsibilities, and } \\
\text { responsiveness/accountability. Such processes also require cooperative learning that involves } \\
\text { stakeholders working in teams to accomplish a common goal, under conditions that involve positive } \\
\text { interdependence and individual and group accountability. }\end{array}$ \\
\hline $\begin{array}{l}\text { Adopt a } \\
\text { strategic } \\
\text { approach to } \\
\text { community } \\
\text { engagement, } \\
\text { creating a } \\
\text { connected } \\
\text { community }\end{array}$ & $\begin{array}{l}\text { Both projects adopted a philosophy of working "with and for" citizens and other stakeholder groups. } \\
\text { Both had to engage stakeholders where they were at. A common goal was to achieve local ownership } \\
\text { of outcomes and deliverables. Both Detroit Riverfront Conservancy and the DRIWR used design } \\
\text { charrettes to solicit ideas, get buy-in, and ensure local ownership. Both the Detroit Riverfront } \\
\text { Conservancy and the DRIWR adopted goals of creating a connected community/constituency. } \\
\text { Substantial resources and time were devoted to ensuring local ownership and a connected } \\
\text { community/constituency. }\end{array}$ \\
\hline $\begin{array}{c}\text { Evoke a sense } \\
\text { of place }\end{array}$ & $\begin{array}{l}\text { Much like the effort to recreate front porches on houses in cities to encourage a sense of community, } \\
\text { the Detroit RiverWalk and DRIWR are good examples of designing and building gathering places for } \\
\text { both people and wildlife. Such convivial places can evoke a sense of place. Understanding places and } \\
\text { what people want and wildlife need are critical to making a place special or unique, and fostering a } \\
\text { sense of authentic human attachment and belonging to an ecosystem. Both DRIWR and Detroit } \\
\text { RiverWalk have excelled at place-making for humans and wildlife. }\end{array}$ \\
\hline $\begin{array}{l}\text { Measure and } \\
\text { celebrate } \\
\text { successes to } \\
\text { sustain } \\
\text { momentum }\end{array}$ & $\begin{array}{l}\text { In any major urban initiative, particularly when the populations affected and number of stakeholder } \\
\text { groups are large, it is important to build a record of success and celebrate it frequently in a very public } \\
\text { fashion. Accomplishments and benefits should be recorded in a fashion that is meaningful to the public } \\
\text { and resonates with them. Both the Detroit Riverfront Conservancy and the DRIWR have been very } \\
\text { effective in using the media to share accomplishments, to tell compelling stories about the project } \\
\text { benefits, and to involve youth and politicians in celebrating successes. }\end{array}$ \\
\hline
\end{tabular}

Finally, the percentage of people in the world living in urban areas has increased from $29 \%$ in 1950 to $54 \%$ in 2014 and is projected to increase to $60 \%$ by 2030 [34]. Today, $80 \%$ of all Americans and 
Canadians live in urban areas. Most urban residents are disconnected from the natural world. Innovative urban waterfront gathering places for people and wildlife can be excellent ways to help inspire the next generation of sustainability entrepreneurs and conservationists in urban areas because that is now where most people on our planet live.

\section{Acknowledgments}

Both the DRIWR and the Detroit Riverfront Conservancy are founded on public-private partnerships. As such, these projects and this manuscript would not be possible without the substantial involvement and support of the many partners too numerous to identify by name. We gratefully acknowledge their important work that laid the foundation for this manuscript. The findings and conclusions in this article are those of the author(s) and do not necessarily represent the views of the U.S. Fish and Wildlife Service.

\section{Author Contributions}

Both authors contributed to this manuscript and approved the final version.

\section{Conflicts of Interest}

The authors declare no conflict of interest.

\section{References}

1. U.S. Department of Commerce; National Oceanic and Atmospheric Administration; Office of Coastal Zone Management; U.S. Department of the Interior; Heritage Conservation and Recreation Service. Improving Your Waterfront: A Practical Guide; U.S. Department of Commerce: Washington, DC, USA, 1980.

2. Marshall, R. Waterfronts in Post-Industrial Cities; Spoon Press: New York, NY, USA, 2001.

3. Levinson, M. Container shipping and the decline of New York, 1955-1975. Bus. Hist. Rev. 2006, 80, 49-80.

4. Kostopoulou, S. Of the revised waterfront: Creative milieu for creative tourism. Sustainability 2013, $5,4578-4593$.

5. Kibel, P.S. Backside Urban: An Introduction. In Rivertown: Rethinking Urban Rivers; Kibel, P.S., Ed.; The Massachusetts Institute of Technology Press: Cambridge, MA, USA, 2007; pp. 1-22.

6. Sieber, R.T. Waterfront Revitalization in Postindustrial Port Cities of North America. City Soc. 1991, 5, 120-136.

7. Hagerman, C. Shaping neighborhoods and nature: Urban political ecologies of urban waterfront transformations in Portland, Oregon. Cities 2007, 24, 285-297.

8. Gravagnuolo, A.; Angrisano, M. Assessment of urban attractiveness of port cities in southern Italy-A case study of Torre Annunziata. Sustainability 2013, 5, 3906-3925.

9. Loures, L. Post-industrial landscapes as drivers for urban redevelopment: Public versus expert perspectives towards the benefits and barriers of the reuse of post-industrial sites in urban areas. Habitat Int. 2015, 45, 72-81.

10. Florida, R. The Rise of the Creative Class; Basic Books: New York, NY, USA, 2011. 
11. Kuhn, T.S. The Structure of Scientific Revolutions; The University of Chicago Press: Chicago, IL, USA, 1962.

12. Cornell, G.L. American Indians at Wawiiatanong: An early american history of indigenous peoples at Detroit. In Honoring Our Detroit River: Caring for Our Home; Hartig, J.H., Ed.; Cranbrook Institute of Science: Bloomfield Hills, MI, USA, 2003; pp. 9-22.

13. Johnson, I.A. The Michigan Fur Trade; The Black Letter Press: Lansing, MI, USA, 1971.

14. Kerr, J.K.; Olinek, W.S.; Hartig, J.H. The Detroit River as an Artery of Trade and Commerce. In Honoring Our Detroit River: Caring for Our Home; Hartig, J.H., Ed.; Cranbrook Institute of Science: Bloomfield Hills, MI, USA, 2003; pp. 35-47.

15. Hartig, J.H. The Rust Belt is Turning Green; iNSnet: Sittard, The Netherlands, 2006.

16. Bruntland, G. Our Common Future; Oxford University Press: Oxford, UK, 1987.

17. Martelle, S. Detroit: A Biography; Chicago Review Press: Chicago, IL, USA, 2012.

18. Hartig, J.H. Bringing Conservation to Cities: Lessons from Building the Detroit River International Wildlife Refuge; Ecovision World Monograph Series; Aquatic Ecosystem Health and Management Society: Burlington, ON, Canada, 2014.

19. Hartig, J.H.; Zarull, M.A.; Ciborowski, J.J.H.; Gannon, J.E.; Wilke, E.; Norwood, G.; Vincent, A. Long-term ecosystem monitoring and assessment of the Detroit River and Western Lake Erie. Environ. Monit. Assess. 2009, 158, 87-104.

20. Hartig, J.H.; Robinson, R.S.; Zarull, M.A. Designing a Sustainable Future through Creation of North America's only International Wildlife Refuge. Sustainability 2010, 2, 3110-3128.

21. Hartig J.H.; Krueger, A.; Rice, K.; Niswander, S.F.; Jenkins, B.; Norwood, G. Transformation of an industrial brownfield into an ecological buffer for Michigan's only Ramsar Wetland of International Importance. Sustainability 2012, 4, 1043-1058.

22. Hemming, B. The Detroit Riverfront Conservancy: A public-private partnership striving to reclaim the Detroit River. Golden Gate Univ. Law Rev. 2005, 35, 1-16.

23. Celebrating Ten Years of Transforming the Riverfront; Detroit Riverfront Conservancy: Detroit, MI, USA, 2013.

24. The Waterfront Center. 2014 Excellence on the Waterfront Award. Available online: http://www.waterfrontcenter.org/Awards/Awards2014/2014Awards.html (accessed 26 October 2015).

25. USA Today. 10 Best American Riverfronts by Readers of USA Today. Available online: http://www.usatoday.com/story/travel/destinations/2014/10/24/best-american-riverfront-10bestreaders-choice-winners/17850025/ (accessed 26 October 2015).

26. CSL International. Economic Impact Study: Detroit Riverfront; Detroit Riverfront Conservancy: Detroit, MI, USA, 2013.

27. Glaeser, E. Vigdor, J. The End of the Segregated Century: Racial Separation in America's Neighborhoods, 1890-2010; Manhattan Institute for Policy Research: New York, NY, USA, 2012.

28. Martin Associates. The Economic Impacts of the Great Lakes-St. Lawrence Seaway System, Lancaster, PA, USA. 18 October 2011. Available online: http://www.greatlakes-seaway.com/ en/pdf/eco_impact_full.pdf (accessed 7 November 2015). 
29. Michigan Department of Natural Resources, Michigan Department of Natural Resources Announces Top 11 Michigan Water Trails, Voted by Public. Available online: http:/www.michigan.gov/ dnr/0,4570,7-153-10365_16839_17259-361315--,00.html (accessed on 18 October 2015).

30. 2015 Detroit River Paddling Guide. Available online: http://www.downrivergreenways.org/home/ reports-and-products (accessed on 18 October 2015).

31. The Active Outdoor Recreation Economy. Available online: http://www.outdoorfoundation.org/pdf/ ResearchRecreationEconomy.pdf (accessed on 18 October 2015).

32. National Survey of Fishing, Hunting, and Wildlife-Associated Recreation. Available online: https://www.census.gov/prod/2012pubs/fhw11-nat.pdf (accessed on 6 November 2015).

33. Senge, P.M. The Fifth Discipline: The Art and Practice of the Learning Organization; Currency Doubleday Books: New York, NY, USA, 1990.

34. United Nations. World Urbanization Prospects, 2014 Revision. http://esa.un.org/unpd/wup/ Highlights/WUP2014-Highlights.pdf (accessed on 31 August 2015).

(C) 2015 by the authors; licensee MDPI, Basel, Switzerland. This article is an open access article distributed under the terms and conditions of the Creative Commons Attribution license (http://creativecommons.org/licenses/by/4.0/). 